ORIGINAL ARTICLE / ARTIGO ORIGINAL

\title{
The International Classification of Functioning, Disability and Health: a systematic review of observational studies
}

\author{
A Classificação Internacional de Funcionalidade, Incapacidade \\ e Saúde: uma revisão sistemática de estudos observacionais
}

Luciana Castaneda', Anke Bergmann", Ligia Bahial

\begin{abstract}
Objective: To systematically review the use of the International Classification of Functioning, Disability and Health (ICF) in observational studies. Methods: This study is a systematic review of articles that use the ICF in observational studies. We took into account the observational design papers available in databases such as PubMed, Lilacs and SciELO, published in English and Portuguese from January 2001 to June 2011. We excluded those in which the samples did not comprise individuals, those about children and adolescents, and qualitative methodology articles. After reading the abstracts of 265 identified articles, 65 met the inclusion criteria. Of these, 18 were excluded. The STROBE (Strengthening the Reporting of Observational Studies in Epidemiology) adapted Checklist, with 15 items needed for observational studies, was applied to the 47 remaining articles. Any paper that met 12 of these criteria was included in this systematic review. Results: 29 articles were reviewed. Regarding the ICF application methodology, the checklist was used in $31 \%$ of the articles, the core set in $31 \%$ and the ICF categories in $31 \%$. In the remaining $7 \%$, it was not possible to define the applied methodology. In most papers (41\%), qualifiers were used in their original format. As far as the area of knowledge is concerned, most of the studies were related to Rheumatology (24\%) and Orthopedics (21\%). Regarding the study design, $83 \%$ of the articles used cross-sectional studies. Conclusion: Results indicate a wide scientific production related to ICF over the past 10 years. Different areas of knowledge are involved in the debate on the improvement of information on morbidity. However, there are only a few quantitative epidemiological studies involving the use of ICF. Future studies are needed to improve data related to functioning and disability. Keywords: International Classification of Functioning, Disability and Health. Chronic disease. Review literature as topic. Data collection. Evidence-based practice.
\end{abstract}

Institute for Studies in Public Health of the Universidade Federal do Rio de Janeiro - Rio de Janeiro (RJ), Brazil.

"Augusto Motta University Center; Instituto Nacional de Câncer - Rio de Janeiro (RJ), Brazil.

Corresponding author: Luciana Castaneda. Avenida Brigadeiro Trompowisky s/n, Praça da Prefeitura da Cidade Universitária, CEP: 21949-900, Rio de Janeiro, RJ, Brasil. E-mail: lucianacastaneda@yahoo.com.br

Conflict of interests: nothing to declare - Financial source: none. 
RESUMO: Objetivo: Realizar uma revisão sistemática sobre o uso da Classificação Internacional de Funcionalidade, Incapacidade e Saúde (CIF) em estudos observacionais. Metodologia: Trata-se de uma revisão sistemática de artigos que utilizaram a CIF em estudos observacionais. Foram incluídos artigos com desenho de estudo observacional disponíveis nas bases de dados do PubMed, Lilacs e SciELO, publicados em inglês e português no período de janeiro a junho de 2011. Foram excluídos aqueles em que a amostra não era composta por indivíduos, os que tratavam sobre crianças e adolescentes, e artigos com metodologia qualitativa. Apos a leitura de 265 resumos identificados, 65 preencheram os critérios de inclusão. Desses, 18 foram excluídos. Nos 47 artigos incluídos foi aplicado o checklist adaptado do Strengthening the Reporting of Observational Studies in Epidemiology (STROBE) que contém 15 itens necessários para estudos observacionais. Artigos que preencheram 12 desses critérios foram incluídos na revisão sistemática. Resultados: Foram incluídos 29 artigos. Em relação à metodologia de aplicação da CIF, o checklist foi utilizado em $31 \%$, o core set em $31 \%$, as categorias da CIF em $31 \%$ e em $7 \%$ não foi possível definir a metodologia. Para o uso dos qualificadores, a aplicação na forma original foi a mais frequente (41\%). Analisando os estudos por área de conhecimento, a maioria deles era referente às áreas de Reumatologia (24\%) e Ortopedia (21\%). Analisando o desenho de estudo, observou-se que $83 \%$ dos artigos eram estudos seccionais. Conclusão: Os resultados indicam um aumento da produção cientifica relacionada à CIF nos últimos 10 anos. Diferentes áreas de conhecimento estão envolvidas no debate sobre a melhoria das informações relacionadas à morbidade. No entanto, apenas um pequeno número de estudos epidemiológicos quantitativos utilizou a CIF. Futuros estudos são necessários para a melhoria dos dados relacionados à funcionalidade e incapacidade.

Palavras-chave: Classificação Internacional de Funcionalidade, Incapacidade e Saúde. Doença crônica. Literatura de revisão como assunto. Coleta de dados. Prática clínica baseada em evidências.

\section{INTRODUCTION}

The measurement of disability and functioning are topics of growing interest from the moment when chronic diseases have shown high prevalence and incidence, with the increase in life expectancy a characteristic phenomenon in modern societies. The inability, in particular, is a subjective and ambiguous category ${ }^{1}$. As a result, the World Health Organization (WHO), for about 30 years, has been developing models for the understanding and classification of the phenomena of functioning, disability and deficiency ${ }^{2}$.

In 1980, the WHO developed a classification to describe the consequences of adverse health conditions or diseases, called the International Classification of Impairments, Disabilities and Handicaps (ICIDH). The aim of this universal model was to provide a biopsychosocial representation of global health, including environmental, social, demographic and psychological contributions. The model consisted of three dimensions: impairment, described as loss or 
alteration in the organs and systems and in the body structure; disability, characterized as any restriction or loss of ability in the performance of basic tasks; and handicap (disadvantage), which reflects the individual's adaptation to the environment resulting from the disability and impairment ${ }^{3}$.

The design of a model of linear causal relation (in which the damage to a body structure or function leads to disability, and this determines a disadvantage for the achievement of social roles) began to suffer criticism and questioning. Among these, there was the progression of a fixed sequence of events based on clinical onsets. Faced with the need of adaptation of the model, several partners from the WHO, together with governmental and nongovernmental organizations, including groups of people with special needs, engaged to review the ICIDH. As a result, in 2001 the WHO approved the International Classification of Functioning, Disability and Health (ICF) ${ }^{4}$.

The ICF is a classification system which describes the functioning and disability related to health conditions, reflecting a new approach which fails to focus only on the consequences of the disease, but also classifies health by biological, individual and social perspective in a multidirectional relation ${ }^{5}$.

In this context, the ICF is a tool created to provide a common language for describing the phenomena related to the health status and it is the most recent and embracing taxonomic model of functioning and disability within a universal and unified perspective. The new model offers a different perspective on impairment and disability, thus overcoming the prevailing biomedical model ${ }^{6}$.

The information is organized into two parts, with two components each. Part 1 (Functioning and Disability) consists of the domains of Body Functions (b) and Body Structures (s) and Activities \& Participation (d). Part 2 (Contextual Factors) is formed by Environmental Factors (e) and by the Personal Factors (not subject to rating yet). The description of functionality involves the presence of a qualifier (which runs on a general scale of 0 to 4 where 0 means no impairment and 4 is a complete failure). The qualifiers show the magnitude of the disability, limitation, restriction, barriers or facilitators of health conditions ${ }^{7}$.

The ICF complements the indicators which traditionally have their focus on deaths or diseases, but they do not adequately capture the impact and consequences of the disease on individuals and on populations. The concepts presented in the classification introduce a new paradigm for thinking and working on impairments and disabilities, perceived not only as a consequence of the conditions of health/disease, but also determined by the context of the physical and social environment, by the different cultural perceptions and attitudes towards disability, by the availability of services and legislation ${ }^{8}$. This model of understanding functioning and disability is essential for the clinical diagnosis of the consequences of health conditions, power assignments as well as the evaluation of the results of the treatment ${ }^{9}$.

Gaidhane et al. ${ }^{10}$ report that the use of ICF quantitatively, as a systematic coding scheme of the information about functioning, disability and handicap, has several advantages, 
such as: standardization of terminology; improvemnt of communication among health professionals; improvement of the data on the subject allowing comparisons among countries, disciplines and services throughout time; usage of the tool in order to identify the nature and magnitude of the multifactorial complex involved in the dimensions of disability and deficiency.

However, studies in Brazilian literature using the ICF quantitatively are scarce. Most of them deal with the concepts of classification and the importance of integration of the tool in the health field. In this sense, the present study aims at conducting a systematic review on the use of the ICF in observational studies. Furthermore, it is one of the objectives to describe how the classification has been used in the areas of knowledge and applied in clinical practice, the way on how to use the qualifiers and the main challenges for the implementation of the tool in clinical practice.

\section{METHODOLOGY}

A systematic review of the literature was conducted, considering, as an inclusion criteria, the publishing of articles with observational characteristics. Those whose sample did not consist on individuals, studies with children and adolescents, and articles on qualitative methodology (case report, focus group and methodology to link the ICF with measuring instruments) were excluded. Publications with the keyword "ICF", available on the data bases of PubMed (US National Library of Medicine), Latin American and Caribbean Literature Data on Health Sciences (LILACS) and Scientific Electronic Library Online (SciELO), published between January and June 2011, in English and Portuguese, were selected. The data were collected during the months of June and July 2011.

Of the 275 articles selected in the initial search, 65 of them were selected after the abstracts were read in full. Of these, 30 were excluded for not meeting the inclusion criteria. For the 35 selected articles, the adapted checklist for Strengthening the Reporting of Observational studies in Epidemiology (STROBE) was applied, an international initiative that encompasses recommendations for the improvement of the quality of the description of observational studies and which contains 15 items needed for these studies. The 29 articles that met 12 out of 15 of the criteria were included for analysis and discussion (Figure 1).

\section{RESULTS}

This systematic review included 29 studies that met the eligibility criteria. Cross-sectional studies were performed by $83 \%$ of the articles, the remaining ones (17\%) conducted prospective cohort studies. Most of them used additional tools for the classification of functioning and disability. Table 1 summarizes the general characteristics of the reviewed studies. 


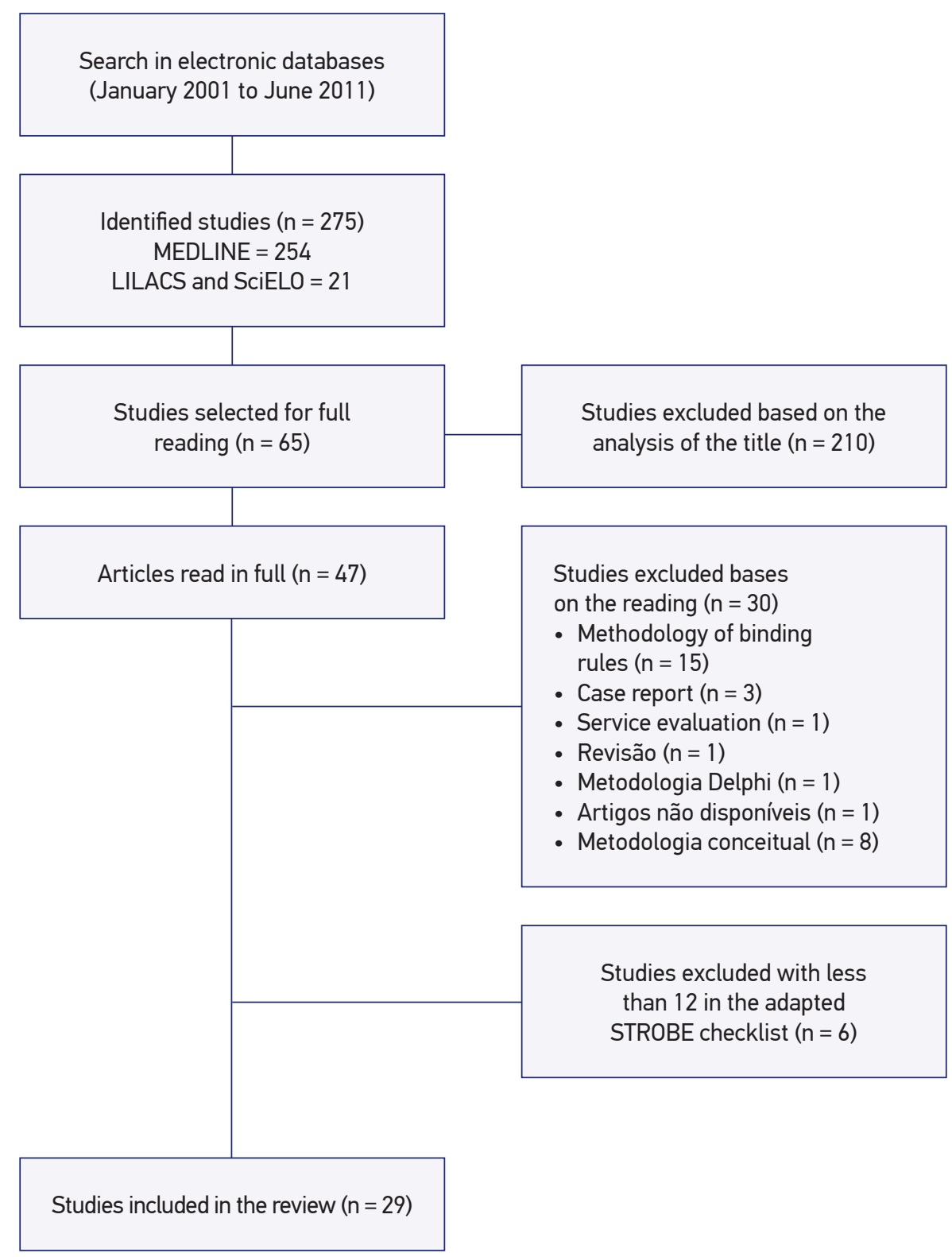

Figure 1. Criteria for identification of studies.

Regarding the method of the ICF use, $31 \%$ of the studies used the checklist, $31 \%$ the corsets and $31 \%$ the ICF categories. In the other $(7 \%)$ it was not possible to define the used method (Figure 2). The qualifiers, in their original form, were used by $41 \%$ of the studies (Figure 3 ).

Analysing the studies by their knowledge areas, most of them related to the areas of Rheumatology (24\%) and orthopedics (21\%) (Figure 4). 
Table 1. Description of the results of the selected studies $(n=29)$.

\begin{tabular}{|c|c|c|c|c|c|c|c|c|}
\hline $\begin{array}{l}\text { Author, } \\
\text { year }\end{array}$ & $\begin{array}{l}\text { Knowledge } \\
\text { area }\end{array}$ & $\begin{array}{l}\text { Design of } \\
\text { the study }\end{array}$ & $\begin{array}{l}\text { General } \\
\text { goal }\end{array}$ & $\begin{array}{l}\text { Population of the } \\
\text { study }\end{array}$ & $\begin{array}{l}\text { Sample } \\
\text { size }\end{array}$ & $\begin{array}{l}\text { ICF Methodology } \\
\text { (Spare cathegories, } \\
\text { checklist or } \\
\text { core set) }\end{array}$ & $\begin{array}{l}\text { Qualifiers } \\
\text { (original or } \\
\text { adapted) }\end{array}$ & $\begin{array}{l}\text { Aditional } \\
\text { instruments }\end{array}$ \\
\hline $\begin{array}{l}\text { Almansa et al., } \\
\qquad 2011^{11}\end{array}$ & Not definable & $\begin{array}{l}\text { Cross- } \\
\text { sectional }\end{array}$ & $\begin{array}{l}\text { To assess whether the validity } \\
\text { scales performance and capacity } \\
\text { can be developed from the } \\
\text { domains of activity and check list } \\
\text { participation }\end{array}$ & $\begin{array}{l}\text { Patients with } 11 \\
\text { different chronic } \\
\text { conditions }\end{array}$ & 1092 & Checklist & Original & $\begin{array}{l}\text { YRSM, HDRS, } \\
\text { MIDAS, EDSS, } \\
\text { MIF }\end{array}$ \\
\hline $\begin{array}{l}\text { Peyrin-Biroulet } \\
\text { et al., } 2011^{12}\end{array}$ & $\begin{array}{l}\text { Internal } \\
\text { Medicine }\end{array}$ & $\begin{array}{l}\text { Cross- } \\
\text { sectional }\end{array}$ & $\begin{array}{l}\text { To develop the first disability index } \\
\text { for inflammatory bowel disease }\end{array}$ & $\begin{array}{l}\text { Patients with } \\
\text { inflammatory } \\
\text { bowel disease }\end{array}$ & 192 & Checklist & Not definable & $\mathrm{x}$ \\
\hline $\begin{array}{l}\text { Gojlar et al., } \\
2011^{13}\end{array}$ & Neurology & Cohort & $\begin{array}{c}\text { To determine whether the ICF } \\
\text { model is adequate for capturing the } \\
\text { patterns of disability }\end{array}$ & $\begin{array}{l}\text { Patients who had } \\
\text { a stroke }\end{array}$ & 197 & Checklist & Original & MIF \\
\hline $\begin{array}{l}\text { Pollard et al., } \\
2011^{14}\end{array}$ & Orthopedics & $\begin{array}{l}\text { Cross- } \\
\text { sectional }\end{array}$ & $\begin{array}{l}\text { To examine the relationship } \\
\text { between disability, limiting } \\
\text { to activities and restriction to } \\
\text { participation }\end{array}$ & $\begin{array}{l}\text { Patients with } \\
\text { osteoarthritis in } \\
\text { situation prior to } \\
\text { the hip and ankle } \\
\text { arthroplasty }\end{array}$ & 413 & Cathegories & Adapted & $\mathrm{x}$ \\
\hline $\begin{array}{l}\text { Virués-Ortega } \\
\text { et al., } 2011^{15}\end{array}$ & Geriatrics & $\begin{array}{l}\text { Cross- } \\
\text { sectional }\end{array}$ & $\begin{array}{l}\text { To report the prevalence of } \\
\text { disability (mild, moderate, severe } \\
\text { and extreme) }\end{array}$ & $\begin{array}{l}\text { Patients with } \\
\text { more than } 75 \\
\text { years of age }\end{array}$ & 503 & Not definable & Original & WHODAS II \\
\hline $\begin{array}{l}\text { Herrmann } \\
\text { et al., } 2011^{16}\end{array}$ & Neurology & $\begin{array}{l}\text { Cross- } \\
\text { sectional }\end{array}$ & $\begin{array}{l}\text { To identify and quantify the } \\
\text { differences in functionality }\end{array}$ & $\begin{array}{l}\text { Patients with } \\
\text { paraplegia and } \\
\text { tetraplegia }\end{array}$ & 1048 & Not definable & Adapted & $\mathrm{x}$ \\
\hline $\begin{array}{l}\text { Gradinger } \\
\text { et al., } 2011^{17}\end{array}$ & Neurology & $\begin{array}{l}\text { Cross- } \\
\text { sectional }\end{array}$ & $\begin{array}{l}\text { To identify the most common } \\
\text { problems in patients with any } \\
\text { degree of disorder of sleep }\end{array}$ & $\begin{array}{l}\text { Patients with } \\
\text { sleep disorders }\end{array}$ & 99 & Checklist & Adapted & $x$ \\
\hline $\begin{array}{l}\text { Rogers et al., } \\
2010^{18}\end{array}$ & Oncology & $\begin{array}{l}\text { Cross- } \\
\text { sectional }\end{array}$ & $\begin{array}{l}\text { To develop a self-administered } \\
\text { questionnaire in order to obtain the } \\
\text { patient's vision over its content }\end{array}$ & $\begin{array}{l}\text { Patients with } \\
\text { head and neck } \\
\text { cancer }\end{array}$ & 364 & Core set & Adapted & UW-QOL \\
\hline
\end{tabular}


Table 1. Continuation.

\begin{tabular}{|c|c|c|c|c|c|c|c|c|}
\hline $\begin{array}{l}\text { Author, } \\
\text { year }\end{array}$ & $\begin{array}{l}\text { Knowledge } \\
\text { area }\end{array}$ & $\begin{array}{l}\text { Design of } \\
\text { the study }\end{array}$ & $\begin{array}{l}\text { General } \\
\text { goal }\end{array}$ & $\begin{array}{l}\text { Population of the } \\
\text { study }\end{array}$ & $\begin{array}{l}\text { Sample } \\
\text { size }\end{array}$ & $\begin{array}{l}\text { ICF Methodology } \\
\text { (Spare cathegories, } \\
\text { checklist or } \\
\text { core set) }\end{array}$ & $\begin{array}{l}\text { Qualifiers } \\
\text { (original or } \\
\text { adapted) }\end{array}$ & $\begin{array}{c}\text { Aditional } \\
\text { instruments }\end{array}$ \\
\hline $\begin{array}{l}\text { Rauch et al., } \\
2009^{19}\end{array}$ & Rheumatology & $\begin{array}{l}\text { Cross- } \\
\text { sectional }\end{array}$ & $\begin{array}{l}\text { To identify similarities and } \\
\text { differences in functionality } \\
\text { in patients with rheumatoid } \\
\text { arthritis (RA) and ankylosing } \\
\text { spondylitis (AS) }\end{array}$ & $\begin{array}{l}\text { Patients with } \\
\text { rheumatoid } \\
\text { arthritis and } \\
\text { ankylosing } \\
\text { spondylitis }\end{array}$ & 230 & Core set & Original & $x$ \\
\hline $\begin{array}{l}\text { Taylor et al., } \\
2010^{20}\end{array}$ & Rheumatology & $\begin{array}{l}\text { Cross- } \\
\text { sectional }\end{array}$ & $\begin{array}{l}\text { To determine the categories of the } \\
\text { checklist and the core set for RA } \\
\text { and AS in patients with frequent } \\
\text { psoriatic arthritis }\end{array}$ & $\begin{array}{c}\text { Patients with } \\
\text { psoriatic arthritis }\end{array}$ & 94 & Checklist & Original & $\begin{array}{l}\text { WHODAS II, } \\
\text { PAR-PRO, } \\
\text { SF-36, Psa- } \\
\text { QOL, HAQ-DI }\end{array}$ \\
\hline $\begin{array}{l}\text { Cieza et al., } \\
2009^{21}\end{array}$ & Orthopedics & $\begin{array}{l}\text { Cross- } \\
\text { sectional }\end{array}$ & $\begin{array}{l}\text { To explore the possibility of building } \\
\text { clinical measures of functionality } \\
\text { by integrating information from } \\
\text { the categories of core set for } \\
\text { osteoarthritis }\end{array}$ & $\begin{array}{l}\text { Patients with } \\
\text { Osteoarthritis }\end{array}$ & 437 & Core set & Original & $x$ \\
\hline $\begin{array}{l}\text { Tsutsui et al., } \\
2008^{22}\end{array}$ & Nephrology & $\begin{array}{l}\text { Cross- } \\
\text { sectional }\end{array}$ & $\begin{array}{l}\text { Identify the most common } \\
\text { problems in Japanese } \\
\text { patients on hemodialysis }\end{array}$ & $\begin{array}{l}\text { Patients on } \\
\text { hemodialysis }\end{array}$ & 136 & $\begin{array}{l}\text { Checklist and } \\
\text { cathegories }\end{array}$ & Not definable & $x$ \\
\hline $\begin{array}{l}\text { Tschiesner } \\
\text { et al., } 2009^{23}\end{array}$ & Oncology & $\begin{array}{l}\text { Cross- } \\
\text { sectional }\end{array}$ & $\begin{array}{l}\text { To access the level of functionality } \\
\text { in patients with head and neck } \\
\text { cancer through the ICF }\end{array}$ & $\begin{array}{l}\text { Patients with } \\
\text { head and neck } \\
\text { cancer }\end{array}$ & 145 & $\begin{array}{l}\text { Checklist and } \\
\text { cathegories }\end{array}$ & Original & EORTC \\
\hline $\begin{array}{l}\text { Hilfiker et al., } \\
\qquad 2009^{24}\end{array}$ & Orthopedics & Cohort & $\begin{array}{l}\text { To evaluate the inter-rater (two } \\
\text { raters) agreement using the core } \\
\text { set for low back pain }\end{array}$ & $\begin{array}{l}\text { Patients with low } \\
\text { back pain }\end{array}$ & 61 & Core set & Adapted & SF-36, SCQ \\
\hline $\begin{array}{l}\text { Rastogi et al., } \\
2008^{25}\end{array}$ & Orthopedics & Cohort & $\begin{array}{l}\text { To quantify the level of importance } \\
\text { on the areas of functionality }\end{array}$ & $\begin{array}{l}\text { Preoperative and } \\
\text { postoperative } \\
\text { patients }\end{array}$ & 54 & Cathegories & Adapted & NPRS, KOOS \\
\hline
\end{tabular}


Table 1. Continuation.

\begin{tabular}{|c|c|c|c|c|c|c|c|c|}
\hline $\begin{array}{l}\text { Author, } \\
\text { year }\end{array}$ & $\begin{array}{l}\text { Knowledge } \\
\text { area }\end{array}$ & $\begin{array}{l}\text { Design of } \\
\text { the study }\end{array}$ & $\begin{array}{l}\text { General } \\
\text { goal }\end{array}$ & $\begin{array}{l}\text { Population of the } \\
\text { study }\end{array}$ & $\begin{array}{l}\text { Sample } \\
\text { size }\end{array}$ & $\begin{array}{l}\text { ICF Methodology } \\
\text { (Spare cathegories, } \\
\text { checklist or } \\
\text { core set) }\end{array}$ & $\begin{array}{l}\text { Qualifiers } \\
\text { (original or } \\
\text { adapted) }\end{array}$ & $\begin{array}{l}\text { Aditional } \\
\text { instruments }\end{array}$ \\
\hline $\begin{array}{l}\text { Bautz-Holter } \\
\text { et al., } 2008^{26}\end{array}$ & Orthopedics & $\begin{array}{l}\text { Cross- } \\
\text { sectional }\end{array}$ & $\begin{array}{l}\text { To evaluate the Norwegian version } \\
\text { of the core set for low back pain } \\
\text { and to investigate the feasibility of } \\
\text { application in clinical practice }\end{array}$ & $\begin{array}{l}\text { Patients with low } \\
\text { back pain }\end{array}$ & 118 & Core set & Original & $\begin{array}{l}\text { SF-36, SCQ, } \\
\text { ODI }\end{array}$ \\
\hline $\begin{array}{l}\text { Xie et al., } \\
2008^{27}\end{array}$ & Orthopedics & $\begin{array}{l}\text { Cross- } \\
\text { sectional }\end{array}$ & $\begin{array}{l}\text { To validate the abbreviated core set } \\
\text { for osteoarthritis }\end{array}$ & $\begin{array}{l}\text { Patients with } \\
\text { Osteoarthritis }\end{array}$ & 122 & Core set & Not definable & SF-36, SCQ \\
\hline Uhlig et al ${ }^{28}$ & Rheumatology & Cohort & $\begin{array}{l}\text { To investigate the responsiveness } \\
\text { of the rheumatoid arthritis core set } \\
\text { in clinical practice }\end{array}$ & $\begin{array}{l}\text { Patients with } \\
\text { rheumatoid } \\
\text { arthritis }\end{array}$ & 46 & Core set & Adapted & MHAQ, SF-36 \\
\hline $\begin{array}{l}\text { Grill e Stucki, } \\
\qquad 2008^{29}\end{array}$ & Not definable & $\begin{array}{l}\text { Cross- } \\
\text { sectional }\end{array}$ & $\begin{array}{c}\text { To examine whether clinical } \\
\text { assessments tomade with the ICF } \\
\text { can be integrated into parametric } \\
\text { scales }\end{array}$ & $\begin{array}{l}\text { Patients with } \\
\text { musculoskeletal } \\
\text { conditions }\end{array}$ & 234 & Core set & Adapted & $x$ \\
\hline $\begin{array}{l}\text { Gaidhane } \\
\text { et al., } 2008^{30}\end{array}$ & Infectology & $\begin{array}{l}\text { Cross- } \\
\text { sectional }\end{array}$ & $\begin{array}{l}\text { To verify the perception of self-care } \\
\text { in patients with HIV/AIDS }\end{array}$ & $\begin{array}{l}\text { Patients with } \\
\text { HIV/AIDS }\end{array}$ & 194 & Cathegories & Original & $x$ \\
\hline $\begin{array}{l}\text { Jonsson et al., } \\
\qquad 2008^{31}\end{array}$ & Neurology & $\begin{array}{l}\text { Cross- } \\
\text { sectional }\end{array}$ & $\begin{array}{l}\text { To describe, through the use of } \\
\text { environmental factors of the ICF, } \\
\text { the social groups that participate in } \\
\text { the life of adults with cerebral palsy }\end{array}$ & $\begin{array}{l}\text { Patients with } \\
\text { cerebral palsy }\end{array}$ & 16 & Cathegories & Original & $x$ \\
\hline $\begin{array}{l}\text { Farin et al., } \\
2007^{32}\end{array}$ & Not definable & $\begin{array}{l}\text { Cross- } \\
\text { sectional }\end{array}$ & $\begin{array}{l}\text { To develop a self-guided } \\
\text { questionnaire for the categories of } \\
\text { mobility and self-care based on ICF }\end{array}$ & $\begin{array}{l}\text { Patients } \\
\text { with various } \\
\text { conditions }\end{array}$ & 1019 & Cathegories & Not definable & $x$ \\
\hline $\begin{array}{l}\text { Verhoef et al., } \\
\qquad 1007^{33}\end{array}$ & Rheumatology & Cohort & $\begin{array}{l}\text { To investigate whether the use } \\
\text { of an instrument based on ICF } \\
\text { improves clinical outcomes and } \\
\text { patient satisfaction with the } \\
\text { multidisciplinary team }\end{array}$ & $\begin{array}{l}\text { Patients with } \\
\text { rheumatoid } \\
\text { arthritis }\end{array}$ & 165 & Cathegories & Not definable & $\begin{array}{c}\text { MACTAR, } \\
\text { RaQol, DAS28 }\end{array}$ \\
\hline
\end{tabular}


Table 1. Continuation.

\begin{tabular}{|c|c|c|c|c|c|c|c|c|}
\hline $\begin{array}{l}\text { Author, } \\
\text { year }\end{array}$ & $\begin{array}{l}\text { Knowledge } \\
\text { area }\end{array}$ & $\begin{array}{l}\text { Design of } \\
\text { the study }\end{array}$ & $\begin{array}{l}\text { General } \\
\text { goal }\end{array}$ & $\begin{array}{l}\text { Population of the } \\
\text { study }\end{array}$ & $\begin{array}{l}\text { Sample } \\
\text { size }\end{array}$ & $\begin{array}{l}\text { ICF Methodology } \\
\text { (Spare cathegories, } \\
\text { checklist or } \\
\text { core set) }\end{array}$ & $\begin{array}{l}\text { Qualifiers } \\
\text { (original or } \\
\text { adapted) }\end{array}$ & $\begin{array}{c}\text { Aditional } \\
\text { instruments }\end{array}$ \\
\hline $\begin{array}{l}\text { Grill et al., } \\
2007^{34}\end{array}$ & Not definable & $\begin{array}{l}\text { Cross- } \\
\text { sectional }\end{array}$ & $\begin{array}{c}\text { To observe an agreement in } \\
\text { description and classification using } \\
\text { the ICF }\end{array}$ & $\begin{array}{l}\text { Patients } \\
\text { with various } \\
\text { conditions }\end{array}$ & 25 & Cathegories & Adapted & $x$ \\
\hline $\begin{array}{l}\text { Echteld et al., } \\
\qquad 2006^{35}\end{array}$ & Rheumatology & $\begin{array}{l}\text { Cross- } \\
\text { sectional }\end{array}$ & $\begin{array}{l}\text { To identify the most common } \\
\text { problems in patients with } \\
\text { ankylosing spondylitis }\end{array}$ & $\begin{array}{l}\text { Patients with } \\
\text { ankylosing } \\
\text { spondylitis }\end{array}$ & 111 & Checklist & Original & SACQ, BASFI \\
\hline $\begin{array}{l}\text { Cieza et al., } \\
2006^{36}\end{array}$ & Not definable & $\begin{array}{l}\text { Cross- } \\
\text { sectional }\end{array}$ & $\begin{array}{c}\text { To propose a method to select ICF } \\
\text { categories when a large amount } \\
\text { of data must be handled and to } \\
\text { identify categories for a } \\
\text { generic core set }\end{array}$ & Not definable & 1.039 & Checklist & Adapted & SF-36 \\
\hline $\begin{array}{l}\text { Zochling et al., } \\
\qquad 2006^{37}\end{array}$ & Rheumatology & $\begin{array}{l}\text { Cross- } \\
\text { sectional }\end{array}$ & $\begin{array}{l}\text { To identify the most common } \\
\text { problems in patients with acute } \\
\text { inflammatory arthritis }\end{array}$ & $\begin{array}{l}\text { Patients } \\
\text { with acute } \\
\text { inflammatory } \\
\text { arthritis }\end{array}$ & 130 & Cathegories & Adapted & $x$ \\
\hline Riberto et al ${ }^{38}$ & Rheumatology & $\begin{array}{l}\text { Cross- } \\
\text { sectional }\end{array}$ & $\begin{array}{l}\text { Description of the results of the } \\
\text { application of core sets for chronic } \\
\text { widespread pain }\end{array}$ & $\begin{array}{l}\text { Patients with } \\
\text { fibromyalgia }\end{array}$ & 29 & Core set & Original & $\mathrm{X}$ \\
\hline $\begin{array}{l}\text { Buchalla e } \\
\text { Cavalheiro }^{39}\end{array}$ & Infectology & $\begin{array}{l}\text { Cross- } \\
\text { sectional }\end{array}$ & $\begin{array}{c}\text { To propose a preliminary version of } \\
\text { the core set for HIV }\end{array}$ & $\begin{array}{l}\text { Patients with } \\
\text { HIV/AIDS }\end{array}$ & 42 & Cathegories & Not definable & $x$ \\
\hline
\end{tabular}

YRSM: Young Rating Scale of Mania; HDRS: Hamilton Depression Rating Scale; MIDAS: Migraine Disability Assessment Questionnaire; EDSS: Expanded Disability Status Scale; MIF: Medida de Independência Funcional; WHODAS II: WHO Disability Assessment Schedule Il; SF-36: Medical Outcomes Study Short-Form 36; PsA-QOL: PsA-Specific QOL linstrument; HAQ-DI: Health Assessment Questionnaire Damage Index; SQC: Social Communication Questionnaire; ODI: Oswestry Disability Index; MHAQ: Modified Health Assessment Questionnaire; BASFI: Bath Ankylosing Spondylitis Functional Index; SACQ: Self-Administered Comorbidity Questionnaire; UW-QOL: University of Washington Quality of Life; NPRS: Numeric Pain Rating Scale; KOOS: Knee Injury and Osteoarthritis Outcome Scale; MACTAR: McMaster Toronto Arthritis Patient Preference Disability Questionnaire; RaQol: Rheumatoid Arthrits Quality of life questionnaire; DAS28: Disease Activity Score. 


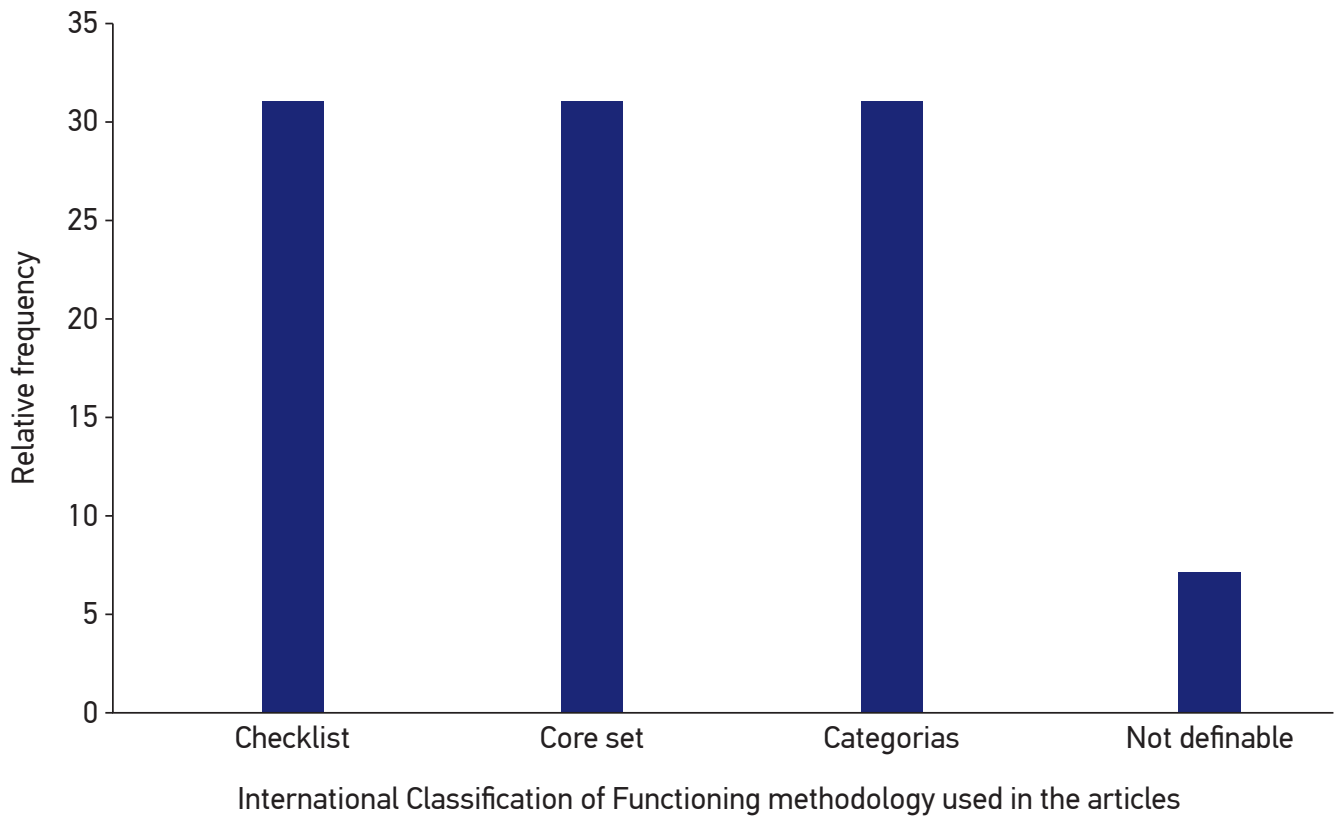

Figure 2. Methodology used in the articles of the International Classification of Functioning included in the systematic review $(n=29)$.

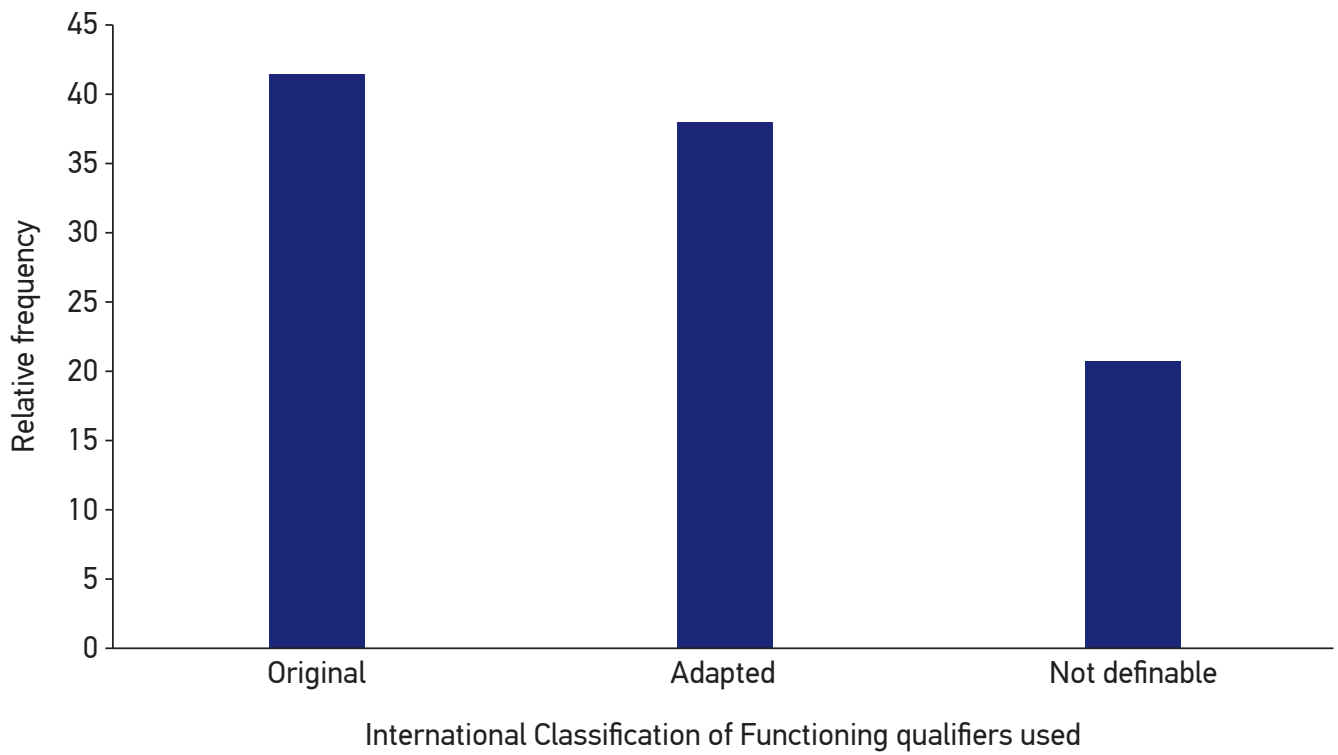

Note: Qualifier was considered adapted when the study did not use it in the original form. The original scale ranges from 0 to 4, and in adaptations, the original scale was categorized dichotomously. Example: Ranked disability as present or absent.

Figure 3. Qualifiers frequency used in the articles of the International Classification of Functioning included in the systematic review $(n=29)$. 


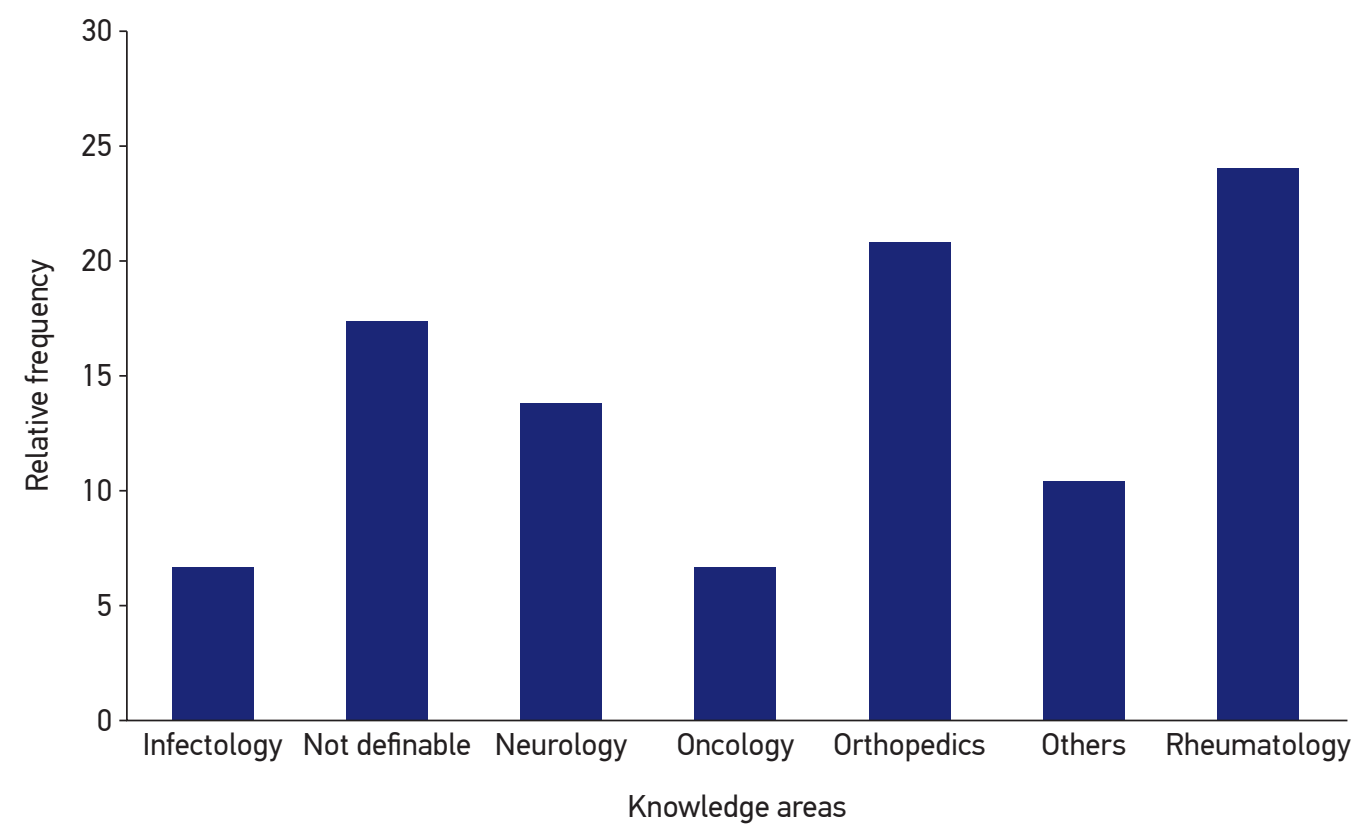

Figure 4. Kowledge areas of the articles of the International Classification of Functioning $(n=29)$.

\section{DISCUSSION}

The ICF appears on the world scenary of rehabilitation as a promising, with high potential of applicability and compliance, tool ${ }^{19}$. Almansa et al. ${ }^{11}$ point out that a major goal of the classification is the systematic recording of information regardless of the method used in order to obtain or access these information. They also evidence that the classification should not be restricted only to the qualitative and/or conceptual use, but it should also be used as a statistical and epidemiological tool. The aim of this study was to conduct a review of the studies which used the ICF quantitatively.

Some years after the publication of the ICF, the WHO has identified that the classification (in their original format, with approximately 1,500 categories) was impractical for everyday use. Thus, it was suggested the development short lists of relevant concepts to specific health conditions and chronic situation. There are two versions of core sets: comprehensive (recommended for research purposes) and abbreviated (for use in clinical practice). Models for stroke, chronic obstructive pulmonary disease, obesity, coronary heart disease, orthopedic conditions, among others have been published and some are still in development ${ }^{38}$. However, the use of core sets is not fully accepted by the scientific community due to the possibility of returning to the biomedical model (focus on the disease and not the functionality).

Our results demonstrate that a large number of articles used the core set in their methodology (31\%), both in the comprehensive and short versions. It was also 
observed that no author used the ICF in its full version and that the articles which used spare ICF categories, mostly, used these categories for assembling questionnaires and clinical assessment scales.

There are some difficulties in implementing the ICF in clinical practice, since this classification does not indicate the instruments needed for the assessment of disability and functionality. The proper use of the instrument depends on the user and the purpose, and there will always be many measurement options, although refinements and changes in classification are necessary. In this sense, Grill et al. ${ }^{32}$ emphasize that the ICF has no psychometric characteristics with defined objective, thus compromising its properties of reliability and validity. It is also noteworthy that the basis for the ICF application, both in clinical practice and in the research field, takes place through the use of practical tools such as core sets.

In a recent review of the implementation and operationalization of ICF since its publication, it was noted that there is an ongoing scientific activity surrounding the spread of classification through theoretical publications in the fields of education, social security and labor. However, only $26 \%$ of publications are related to the clinical practice and/or rehabilitation. The authors conclude that the greater the availability of tools guided by the ICF, the better the data on population health within the information systems ${ }^{39}$. However, such review was qualitative and its results should be interpreted with caution. The results demonstrated the predominance of cross-sectional studies (83\%). This, points to the difficulty of introducing the ICF in longitudinal epidemiological studies.

In another systematic review, Jelsma ${ }^{40}$ concluded that the ICF, over the past few years, made a big impact on how data on deficiency and disability are conceptualized, collected and processed. He stressed that the classification has been used in various disciplines, health conditions, sectors and settings, and that the use of the ICF in developing countries should be encouraged. The results show a small scientific production using the ICF in Latin America. This can be explained by the fact that the number of studies identified on the basis of Lilacs was much lower than the number identified in the PubMed database.

Another limiting issue is that the fact qualifiers require standardization and that they present some difficulty in their psychometric characteristics. Goljar et al. ${ }^{13}$ highlight that the use of the ICF qualifiers is not yet fully operationalized, although many attempts have been made towards the validation of the use of operational scales. However, such difficulties and obstacles will only be solved if there is adherence by professionals and a practical use of the ICF. Our results indicate that about $35 \%$ of the studies used the qualifiers in an adapted way, which goes against the difficulties found by many authors. These authors usually adapt the qualifiers for dichotomous response option, thus providing a prevalence measure of the disability and not an analysis of the phenomenon of gravity. This adaptation is not consistent with the original model of the ICF. 
The objective of this systematic review was to demonstrate how the ICF has been used in observational studies, however, a limitation of this study is the fact that the quality of the articles was not analyzed. In an attempt to reduce this problem, an adapted version of the STROBE was used. The checklist of the initiative is not an evaluative document, however, the choice of using it was an attempt to elect the authors with better methodological quality. The adapted document consisted of 15 questions and articles that reached 12 positive responses were included. The cutoff point chosen was subjective.

The results found in this review may be a starting point for future discussions involving the quantitative aspects of the ICF. Questions about the methodology involving or not the use of core sets, psychometric properties of the qualifiers and areas of knowledge yet with little participation can be explored in future studies.

\section{CONCLUSION}

The results indicate a wide scientific production related to the International Classification of Functioning, Disability and Health over the past 10 years. Several knowledge areas and sectors of the health field are involved in the debate on the improvement of information on morbidity. However, the quantitative epidemiological studies involving the use of ICF in clinical practice are few, if compared to the qualitative studies. Future studies are needed in order to improve the secondary data related to functioning and disability.

\section{REFERENCES}

1. Jette AM. Toward a common language for function, disability and health. Phys Ther 2006; 86(5): 726-34.

2. Stucki G, Cieza A, Melvin J. The International Classification of Functioning, Disability and Health (ICF): a unifying model for the conceptual description of the rehabilitation strategy. J Rehabil Med 2007; 39(4): 279-85

3. World Health Organization (WHO). International classification of impairments, disabilities, and handicaps (ICIDH). Geneva; 1980.

4. World Health Organization (WHO). The International Classification of Functioning, Disability and Health: 2001. Geneva; 2001.

5. McIntyre A, Tempest S. Two steps forward, one step back? A commentary on the disease-specific core sets of the International Classification of Functioning, Disability and Health (ICF). Disabil Rehabil 2007; 29(18): 1475-9.
6. Stucki, G. International Classification of Functioning, Disability, and Health (ICF): a promising framework and classification for rehabilitation medicine. A J Phys Med Rehabil 2005; 84 (10): 733-40.

7. Kuijer W, Brouwer S, Preuper HR, Groothoff JW, Geertzen JH, Dijkstra PU. Work status and chronic low back pain: exploring the International Classification of Functioning, Disability and Health. Disabil Rehabil 2006; 28(6): 379-88.

8. Stucki G, Cieza A, Ewert T, Kostanjsek N, Chatterji S, Ustün T. Application of the International Classification of Functioning, Disability and Health (ICF) in clinical practice. Disabil Rehabil 2002; 24(5): 281-2.

9. Cieza A, Hilfiker R, Chatterji S, Kostanjsek N, Ustün BT, Stucki G. The International Classification of Functioning, Disability, and Health could be used to measure functioning. J Clin Epidemiol 2009; 62(9): 899-911. 
10. Gaidhane AM, Zahiruddin QS, Waghmare L, Zodpey S, Goyal RC, Johrapurkar SR. Assessing self-care component of activities and participation domain of the international classification of functioning, disability and health (ICF) among people living with HIV/AIDS. AIDS Care 2008; 20(9): 1098-104.

11. Almansa J, Ayuso-Mateos JL, Garin O, Chatterji $\mathrm{S}$, Kostanjsek N, Alonso J, et al. The international classification of functioning, disability and health: development of capacity and performance scales. J Clin Epidemiol 2011; 64(12): 1400-11.

12. Peyrin-Biroulet L, Cieza A, Sandborn WJ, Coenen M, Chowers Y, Hibi T, et al. Development of the first disability index for inflammatory bowel disease based on the international classification of functioning, disability and health. Gut 2012; 61(2): 241-7

13. Goljar N, Burger H, Vidmar G, Leonardi M, Marincek C. Measuring patterns of disability using the International Classification of Functioning, Disability and Health in the post-acute stroke rehabilitation setting. J Rehabil Med 2011; 43(7): 590-601.

14. Pollard B, Johnston M, Dieppe P. Exploring the relationships between International Classification of Functioning, Disability and Health (ICF) constructs of Impairment, Activity Limitation and Participation Restriction in people with osteoarthritis prior to joint replacement. BMC Musculoskelet Disord 2011; 12: 97-105.

15. Virués-Ortega J, de Pedro-Cuesta J, Seijo-Martínez M, Saz P, Sánchez-Sánchez F, Rojo-Pérez F, et al. Prevalence of disability in a composite $\geq 75$ year-old population in Spain: a screening survey based on the International Classification of Functioning. BMC Public Health 2011; 11: 176-87.

16. Herrmann KH, Kirchberger I, Biering-Sørensen F, Cieza A. Differences in functioning of individuals with tetraplegia and paraplegia according to the International Classification of Functioning, Disability and Health (ICF). Spinal Cord 2011; 49(4): 534-43.

17. Gradinger F, Glässel A, Gugger M, Cieza A, Braun $\mathrm{N}$, Khatami R, et al. Identification of problems in functioning of people with sleep disorders in a clinical setting using the International Classification of Functioning Disability and Health (ICF) Checklist. J Sleep Res 2011; 20(3): 445-53.

18. Rogers SN, Forgie S, Lowe D, Precious L, Haran $\mathrm{S}$, Tschiesner U. Development of the International Classification of Functioning, Disability and Health as a brief head and neck cancer patient questionnaire. Int J Oral Maxillofac Surg 2010; 39(10): 975-82.

19. Rauch A, Cieza A, Boonen A, Ewert T, Stucki G. Identification of similarities and differences in functioning in persons with rheumatoid arthritis and ankylosing spondylitis using the International Classification of Functioning, Disability and Health (ICF). Clin Exp Rheumatol 2009; 27(4 Suppl 55): S92-101.

20. Taylor WJ, Mease PJ, Adebajo A, Nash PJ, Feletar M, Gladman DD. Effect of psoriatic arthritis according to the affected categories of the international classification of functioning, disability and health. J Rheumatol 2010; 37(9): 1885-91.

21. Tsutsui H, Koike T, Yamazaki C, Ito A, Kato F, Sato H, et al. Identification of hemodialysis patients' common problems using the International Classification of Functioning, Disability and Health. Ther Apher Dial 2009; 13(3): 186-92.

22. Tschiesner U, Linseisen E, Baumann S, Siedek V, Stelter $\mathrm{K}$, Berghaus A, et al. Assessment of functioning in patients with head and neck cancer according to the International Classification of Functioning, Disability, and Health (ICF): a multicenter study. Laryngoscope 2009; 119(5): 915-23.

23. Hilfiker R, Obrist S, Christen G, Lorenz T, Cieza A. The use of the comprehensive International Classification of Functioning, Disability and Health Core Set for low back pain in clinical practice: a reliability study. Physiother Res Int 2009; 14(3): 147-66.

24. Rastogi R, Chesworth BM, Davis AM. Change in patient concerns following total knee arthroplasty described with the International Classification of Functioning, Disability and Health: a repeated measures design. Health Qual Life Outcomes 2008; 6: 112-20.

25. Bautz-Holter E, Sveen U, Cieza A, Geyh S, Røe C. Does the International Classification of Functioning, Disability and Health (ICF) core set for low back pain cover the patients' problems? A cross-sectional content-validity study with a Norwegian population. Eur J Phys Rehabil Med 2008; 44(4): 387-97.

26. Xie F, Lo NN, Lee HP, Cieza A, Li SC. Validation of the International Classification of Functioning, Disability, and Health (ICF) Brief Core Set for osteoarthritis. Scand J Rheumatol 2008; 37(6): 450-61.

27. Uhlig T, Moe R, Reinsberg S, Kvien TK, Cieza A, Stucki G. Responsiveness of the International Classification of Functioning, Disability and Health (ICF) Core Set for rheumatoid arthritis. Ann Rheum Dis 2009; 68(6): 879-84.

28. Grill E, Stucki G. Scales could be developed based on simple clinical ratings of International Classification of Functioning, Disability and Health Core Set categories. J Clin Epidemiol 2009; 62(9): 891-8.

29. Jönsson G, Ekholm J, Schult ML. The International Classification of Functioning, Disability and Health environmental factors as facilitators or barriers used in describing personal and social networks: a pilot study of adults with cerebral palsy. Int J Rehabil Res 2008; 31(2): 119-29. 
30. Farin E, Fleitz A, Frey C. Psychometric properties of an International Classification of Functioning, Disability and Health (ICF)-oriented, adaptive questionnaire for the assessment of mobility, self-care and domestic life. J Rehabil Med 2007; 39(7): 537-46.

31. Verhoef J, Toussaint PJ, Zwetsloot-SchonkJH, Breedveld FC, Putter H, Vliet Vlieland TP. Effectiveness of the introduction of an International Classification of Functioning, Disability and Health-based rehabilitation tool in multidisciplinary team care in patients with rheumatoid arthritis. Arthritis Rheum 2007; 57(2): 240-8.

32. Grill E, Mansmann U, Cieza A, Stucki G. Assessing observer agreement when describing and classifying functioning with the International Classification of Functioning, Disability and Health. J Rehabil Med 2007; 39(1): 71-6.

33. van Echteld I, Cieza A, Boonen A, Stucki G, Zochling $\mathrm{J}$, Braun J, et al. Identification of the most common problems by patients with ankylosing spondylitis using the international classification of functioning, disability and health. J Rheumatol 2006; 33(12): 2475-83.

34. Cieza A, Geyh S, Chatterji S, Kostanjsek N, Ustün BT, Stucki G. Identification of candidate categories of the International Classification of Functioning Disability and Health (ICF) for a Generic ICF Core Set based on regression modelling. BMC Med Res Methodol 2006; 6: 36-48.

35. Zochling J, Grill E, Scheuringer M, Liman W, Stucki G, Braun J. Identification of health problems in patients with acute inflammatory arthritis, using the International Classification of Functioning, Disability and Health (ICF). Clin Exp Rheumatol 2006; 24(3): 239-46.

36. Riberto M, Saron TRP, Battistella LR. Resultados do core set da CIF de dor crônica generalizada em mulheres com fibromialgia no Brasil. Acta Fisiátrica 2008; 15(1): 6-12.

37. Buchalla CM, Cavalheiro T. Classificação Internacional de Funcionalidade, Incapacidade e Saúde e a Aids: uma proposta de core set. Acta Fisiátrica 2008; 15(1): 42-8.

38. Ustün B, Chatterji S, Kostanjsek N. Comments from WHO for the Journal of Rehabilitation Medicine Special Supplement on ICF core sets. J Rehabil Med 2004; (44 Suppl): 7-8.

39. Cerniauskaite M, Quintas R, Boldt C, Raggi A, Cieza A, Bickenback JE, et al. Systematic literature review on ICF from 2001 to 2009: its use, implementation and operationalization. Disabil Rehabil 2011; 33(4): 281-309.

40. Jelsma J. Use of the International Classification of Functioning, Disability and Health: a literature survey. J Rehabil Med 2009; 41(1): 1-12.

Received on: 08/28/2012

Final version presented on: 10/07/2013

Accepted on: 01/16/2014 